\title{
PERI-IMPLANT STRAINS WITH BALL AND TELESCOPIC ATTACHMENTS FOR IMPLANT SUPPORTED MAXILLARY OVERDENTURES. AN INVITRO STRAIN GAUGE ANALYSIS
}

\author{
Amr Abd El Bary Mahdy Emarah* and Shahinaz Sayed Mohamed Hassan**
}

\begin{abstract}
Purpose: This invitro study evaluates peri-implant strains with ball and telescopic attachments for implant supported maxillary overdentures.

Materials and methods: A model represent an edentulous maxillary ridge with 4 implants installed at both canine and second premolar areas was constructed. Experimental maxillary overdentures were fabricated and attached to the implants with rigid telescopic (TA, n=5), and ball $(B A, n=5)$ attachments. Two strain gauges were bonded to the acrylic resin at buccal and palatal surfaces of each implant. Strains were measured during unilateral load application on the $1^{\text {st }}$ molar region of the right (loading) side. Mann-Whitney test was used to compare microstrains between groups (TA, and BA), implant positions (canine and premolar implants) and strain gauge positions (buccal and palatal gauges on right and left sides).
\end{abstract}

Results: For all strain gauge positions of canine and premolar implants, TA showed significant higher microstrain than BA. For both groups, palatal loading side showed the highest microstrain for canine implants, and buccal loading side showed the highest microstrain for premolar implants. For palatal gauges on both sides, canine implants recorded significant higher strain than premolar implants. For buccal gauges on both sides, premolar implants recorded significant higher strain than canine implants.

Conclusion: Within limitation of this invitro study, it could be concluded that, ball attachments are recommended to retain maxillary implant overdenture than telescopic attachments as it were associated with reduced peri-implant strain.

\section{INTRODUCTION}

Maxillary implant overdenture (MIOD) is considered an alternative treatment modality to implant supported fixed restorations in many clinical situations such as atrophied maxillary ridges, buccal inclination of premaxillary bone, high smile line, lack of keratinized mucosa, and inadequate lip support ${ }^{1,2}$. Moreover, MIODs may

* Lecturer, Department of Removable Prosthodontics, Faculty of Dentistry, Fayoum University, Fayoum, Egypt ** Assistant Professor, Department of Removable Prosthodontics, Faculty of Dentistry, Beni-Suef University, Egypt. 
be advantageous with unfavorable jaw relations ${ }^{3}$ and for subjects with implant assisted overdentures in mandibular ridge to prevent damage of maxillary ridge tissues ${ }^{4}$. Furthermore, they can provide an emergency treatment when implants fail and help in load distribution between the implants and mucosa if the bone quality is compromised ${ }^{1}$. MIOD may be connected to the implants with different anchors such as bars (egg shaped or milled), ball and sockets attachments, resilient studs (Locators), magnets and telescopic (double crown) attachments.

Telescopic attachments consist of an inner and outer coping which can provide several advantages such as good frictional retention and stability, splinting in cases where bars are contraindicated, less technical complications and more access for oral hygiene ${ }^{5}$. They also prevent excellent horizontal stability in case of atrophied ridges ${ }^{6}$. Telescopic attachments may be rigid ones which include friction parallel walls or the conical, and the non-rigid (resilient) ones. Rigid telescopic crowns direct occlusal contact between inner and outer copings. They achieve retention using the friction of parallel-sided milled surfaces of the inner and outer crowns during insertion and removal. Conical (tapered) telescope crowns exhibit friction only when completely seated using a "wedging effect." "7,8,6. Telescopic attachments have proved clinical efficiency in terms of peri-implant tissue health, patient satisfaction, chewing efficiency, and masseter muscle activity when used for mandibular overdentures ${ }^{9-12}$.

Ball anchors are used widely for implantsupported overdentures as it is simple, effective and has reduced cost when compared to locators and telescopic crowns ${ }^{13-15}$. Ball and socket attachments offer high wear resistance and provided additional stability, retention, and support ${ }^{16}$. It is also less technique sensitive ${ }^{2}$ compared to telescopic and bar attachments and resilient in both vertical and lateral directions ${ }^{17}$. The specific design of the ball attachment may influence the amount of its free movement, thereby limiting its resiliency. ${ }^{18}$. However, ball attachments had a high number of prosthetic complications than bar $^{19}$ and telescopic ${ }^{20}$ attachments such as replacement of matrix cap and replacement of matrix it self

The selection of the attachment type should consider 2 important factors; the degree of retention needed, and load transmission to the implants and peri-implant bone ${ }^{21}$. The attachment design and retention mechanism may significantly influence stress/strain magnitude around implants. ${ }^{22}$. Excessive loads applied to the implant may cause pathologic stresses and strains in the crestal bone stimulating resorption ${ }^{23}$.

In several invitro studies ${ }^{24,25}$, the retention and stability forces of different rigid and resilient attachment mechanisms used for maxillary overdentures were investigated. However, the stresses in the bone around the implants supporting such overdentures with different attachments were not sufficiently evaluated ${ }^{26}$. Few studies ${ }^{26,27}$ investigated the influence of attachment type of maxillary implant overdentures on load transmitted to the peri-implant regions. Kazokoğlu and Akaltan ${ }^{27}$ concluded that Marburg double crown on four implants supporting maxillary overdentures may be used without rigid connectors without negative effect on peri-implant or edentulous ridge strains. The aim of the current investigation was to evaluate the peri-implant strains with ball and rigid telescopic attachments for implant supported maxillary overdentures. The authors hypothesized that no difference in peri-implant strains between tested anchors would occur.

\section{MATERIALS AND METHODS}

\section{Experimental models and overdentures}

This in-vitro experiment was performed on a model that represents an edentulous maxillary ridge. A trial denture base was constructed over the model with complete setup of acrylic teeth. The denture 
base was duplicated into clear heat cure acrylic resin to be used as a guide for implant placement. Four implants installed at both canine and second premolar areas using the clear acrylic guide. Four $4.2 \times 12 \mathrm{~mm}$ implants (Dentaururm, Ispringen, Germany) were attached in the canine and second premolar regions bilaterally parallel to each other's using auto-polymerized acrylic resin to simulate bone bonding ${ }^{28,29}$. The remaining ridge and the palatal vault with after covered with after $1.5 \mathrm{~mm}$ thickness of resilient liner to simulate the natural mucosa ${ }^{30,31}$. A layer of baseplate wasx was adapted over the cast and the cast was flasked. After wax elimination, autopolymerized resilient acrylic resin soft liner (Acrostone, Egypt) was packed into the mold.After curing, the excess soft liner was removed and the model was finished. Ten experimental maxillary overdentures (5 overdenture/group) were fabricated and attached to the implants using rigid telescopic (TA, $n=5)$, and ball and socket (BA, $n=5)$ attachments.

For TA group, plastic caps of Ti-base abutments were contoured with wax and milled using a parallometer milling device (AMANNGIRRBACH, Austria), cast in cobalt chromium alloy (BEGO Bremer, Herbst GmbH, Germany), then refined again by milling to produce inner crowns. The outer copings were waxed over the inner copings, invested, and cast in the same alloy. Any necessary adjustment was made using the fit checker paste and then finished and polished (fig. 1). For BA, ball abutments (Dentaururm, Ispringen, Germany, gingival height $=3 \mathrm{~mm}$ ) were screwed to the implants, and the metal sockets with were snapped over the abutments (fig. 2). Experimental overdentures consisted of denture bases and occlusion rims (constructed from heat cure acrylic resin) without denture teeth and with occlusal plane parallel to the crest of the ridge (fig. 3). Secondary copings of the telescopic attachments and metal sockets of the ball attachments were picked up to the fitting surface of experimental overdentures with self-cure acrylic resin in 2 occasions. Firstly, telescopic primary crowns $(n=4)$ were connected to the implants. Sufficient relieve in the fitting surface of the dentures $(n=5)$ was provided, then and secordary crowns $(n=20,4$ for each overdenture) were picked up to the experimental overdentutre. Secondly, telescopic primary crowns were replaced by ball abutments $(n=4)$. Sufficient relieve in the fitting surface of the dentures $(n=5)$ was provided, then and metal sockets ( $n=20,4$ for each overdenture) were picked up to the experimental overdentutre.

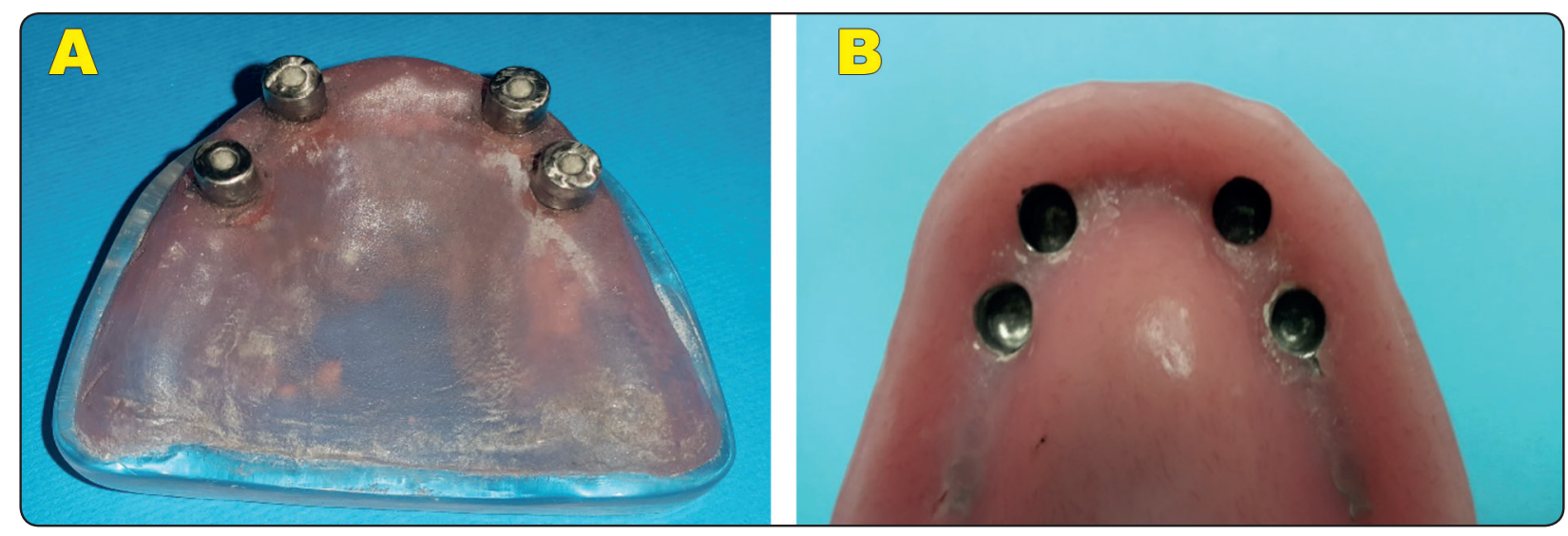

Fig. (1) Telescopic overdentures (TA); a; The primary crowns, b; The secondary crowns attached to the dentures 


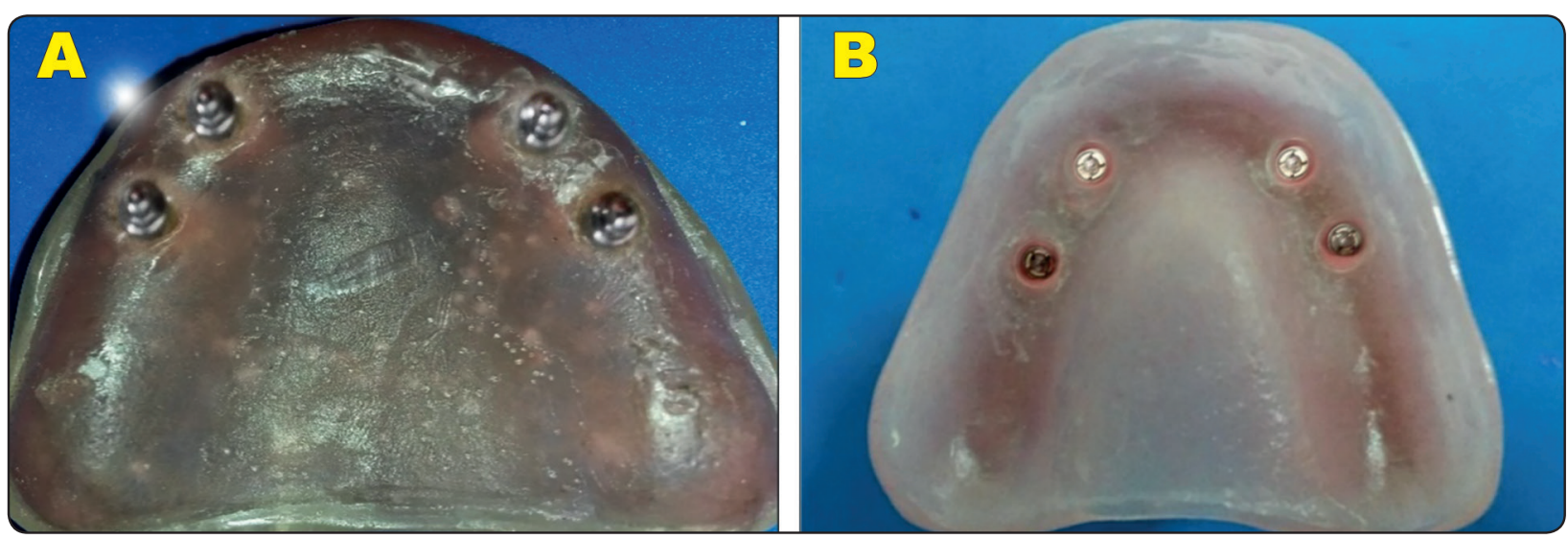

Fig. (2) Ball overdentures (BA); a; The ball abutments, b; The metal sockets attached to the dentures

\section{Strain measurements}

The silicone soft liner simulating the mucosa was removed with sharp scalpel from bucall and palatal surface of each implant. The surface of acrylic resin was prepared to be flat. Two strain gauges (KFG1-120-C1-11L1M2R, Gauge factor=2.8 $\pm 1.0 \%$, Gauge length $=1 \mathrm{~mm}$, Kyowa, Tokyo, Japan) were luted to the surface of the acrylic resin at buccally and palatally around each implant using a special type of bonding agent supplied by the manufacture (CC-33A) to measure strains on the surface that indicate the moments occur in the peri-implant crestal region ${ }^{8}$. Bonding agent was painted to the falt surface and long axes of the strain gauges were oriented parallel to the long axes of the implant (fig 3). Using a celluloid sheet provided by the manufacture, a finger pressure was excerted over the gauge to fix them to the surface of acrylic resin. The wires of the 8 gauges were attached to a digital device that measures strain (Tinsley, London, UK). The connection was established in a quarter bridge circuit which convert resistance change of the gauges to microvoltage output (microstrains, $\mu \mathrm{s}$ ) by a compatible software (Kywa PCD 300A). Before measurements, calibration of the gauges was made to test the repeatability of strain measurements. The simulation model was attached to a loading apparatus with occlusal plane oriented parallel to the floor. A universal testing device (LLOYD,

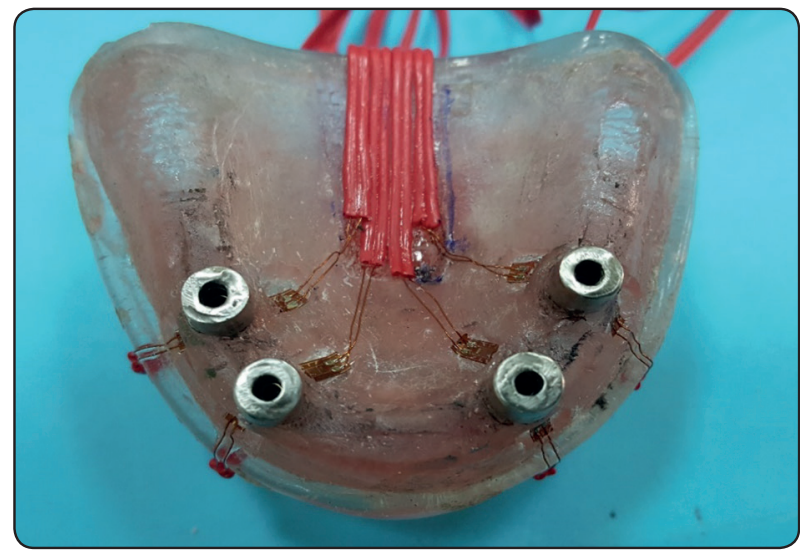

Fig. (3). Strain gauge fixation on buccal and palatal periimplant positions

Hampshire, UK) was used to apply $100 \mathrm{~N}$ vertical unilateral static load (similar to loads excreted implant overdenture patients ${ }^{32}$ on the first molar region of the right (loading) side using loading pin (cross head speed $=0.5 \mathrm{~mm} \backslash \mathrm{min}$ ) (fig4). The left half of the occlusion block was assumed as the nonloading side. All testes were performed 5 times for each overdenture, with a 5 minutes interval period between test for heat release, and the mean obtained values was used in the analysis ${ }^{29,30,33,34}$.

\section{Statistical analysis}

General linear model was used to test differences in microstrains between attachments (TA, and BA), 


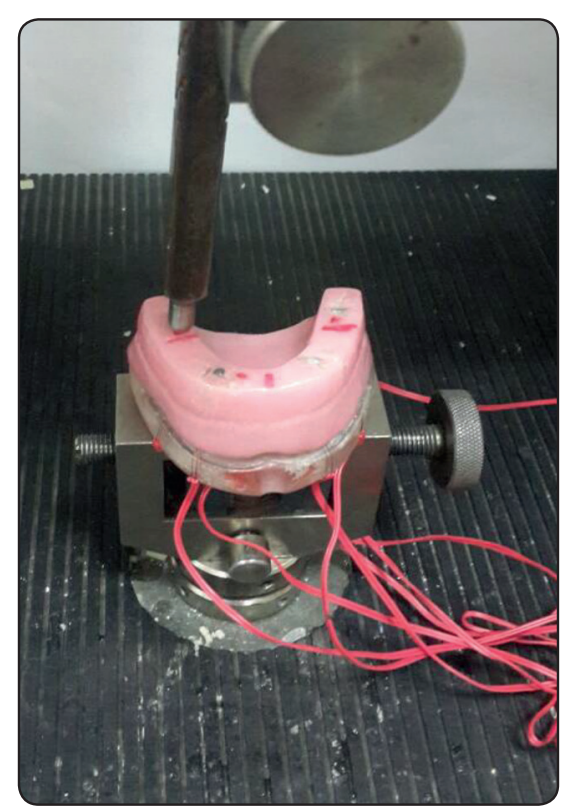

Fig (4). Unilateral loading using the loading pin of the universal testing machine

implant positions (canine and premolar implants) and strain gauge positions (buccal/loading side, palatal/loading side, buccal/non-loading side and palatal/non-loading side). Bonferroni post hoc test was used for correction. $\mathrm{P}<.05$ was considered significant at confidence interval $95 \%$.

\section{RESULTS}

Main effects of factors involved in the statistical model on the recorded strains are presented in table 1. The total microstrain values differ significantly between groups $(\mathrm{p}=.001)$, implant positions $(\mathrm{p}=.002)$, and strain gauge position $(\mathrm{p}=.003)$. TA recorded significant higher total microstrains than BA. Canine implants recorded significant higher total microstrains than premolar implants. Buccal/ loading side strain gauges showed the highest total microstrains, then palatal/loading side, palatal/nonloading side and buccal/non-loading side recorded the lowest strains. There was a significant interaction between group* implant position $(\mathrm{F}(2,95)=45.280$, $\mathrm{p}<.001)$, group* strain gauge position $(\mathrm{F}(6,95)=$ 1019.038, $\mathrm{p}<.001)$, implant position* strain gauge position $(\mathrm{F}(3,95)=711.779, \mathrm{p}<.001)$ and Group* implant position* strain gauge position $(\mathrm{F}(6,95)=$ $578.250, \mathrm{p}<.001)$

\section{Effect of groups}

For all strain gauge positions of canine implants (except buccal/ non-loading side), TA showed significant higher microstrains than BA. For all strain gauge positions of premolar implants, TA showed significant higher microstrains than BA (table 2).

\section{Effect of strain gauge positions}

For both groups at canine implants, palatal loading side had the highest microstrains, and the buccal/non-loading recorded the lowest microstrains. For both groups at premolar implants, buccal loading showed the highest microstrains, and the buccal non-loading recorded the lowest microstrains (table 2).

\section{Effect of implant positions}

For both groups at palatal loading and palatal nonloading sides, canine implants recorded significant higher strain than premolar implants. For both groups at buccal loading and buccal non-loading sides, premolar implants recorded significant higher strain than canine implants (fig5). 
TABLE (1) Main effect of factors involved in the statistical model on the registered microstrains

\begin{tabular}{|c|c|c|c|c|c|}
\hline & Mean & St. error & F value & $\begin{array}{c}\text { ANOVA } \\
\text { P value }\end{array}$ & $\begin{array}{c}\text { Post hoc test } \\
\text { (Tukey) }\end{array}$ \\
\hline \multicolumn{6}{|c|}{ Groups } \\
\hline TA & 120.50 & 42.48 & \multirow[b]{2}{*}{3187.508} & \multirow[b]{2}{*}{$.001 *$} & - \\
\hline BA & 14.125 & 6.24 & & & - \\
\hline \multicolumn{6}{|c|}{ Implant positions } \\
\hline Canine implants & 51.667 & 21.57 & \multirow{2}{*}{9.484} & \multirow{2}{*}{$.002 *$} & - \\
\hline Premolar implants & 47.833 & 18.16 & & & - \\
\hline \multicolumn{6}{|c|}{ Strain gauge positions } \\
\hline Buccal/loading & 112.833 & 37.76 & \multirow{4}{*}{1283.689} & \multirow{4}{*}{$.003 *$} & A \\
\hline Palatal/loading & 44.500 & 19.34 & & & B \\
\hline Buccal/non-loading & 10.500 & 3.29 & & & $\mathrm{C}$ \\
\hline Palatal/non-loading & 33.167 & 10.03 & & & $\mathrm{D}$ \\
\hline
\end{tabular}

*P is significant at .05 . The same letters show no significant difference between levels of each factor

TABLE (2) Comparison of microstrain between attachments and strain gauges

\begin{tabular}{|c|c|c|c|c|c|c|}
\hline & \multicolumn{3}{|c|}{ Canine implants } & \multicolumn{3}{|c|}{ Premolar implants } \\
\hline & $\mathrm{TA}$ & BA & $P$ value & TA & BA & $P$ value \\
\hline $\begin{array}{l}\text { Buccal/ loading } \\
\qquad(\mathrm{X} \pm \mathrm{SD})\end{array}$ & $\begin{array}{c}137.00 \pm 10.62 \\
\mathrm{~A}\end{array}$ & $\begin{array}{c}19.00 \pm 3.74 \\
\mathrm{~A}\end{array}$ & $<.001 *$ & $\begin{array}{c}418.00 \pm 5.47 \\
\mathrm{~A}\end{array}$ & $\begin{array}{c}28.00 \pm 6.06 \\
\mathrm{~A}\end{array}$ & $<.001 *$ \\
\hline $\begin{array}{l}\text { Palatal/loading } \\
\quad(\mathrm{X} \pm \text { SD })\end{array}$ & $\begin{array}{c}156.00 \pm 10.75 \\
\mathrm{~B}\end{array}$ & $\begin{array}{c}35.00 \pm 3.74 \\
\mathrm{~B}\end{array}$ & $<.001 *$ & $\begin{array}{c}100.00 \pm 6.25 \\
B\end{array}$ & $\begin{array}{l}10.00 \pm 2.14 \\
\mathrm{~B}\end{array}$ & $<.001 *$ \\
\hline $\begin{array}{l}\text { Buccal/Non-loading } \\
\text { (X } \pm \text { SD })\end{array}$ & $\begin{array}{c}12.00 \pm 3.24 \\
\mathrm{C}\end{array}$ & $\begin{array}{c}11.00 \pm 1.74 \\
\mathrm{C}\end{array}$ & .086 & $\begin{array}{c}30.00 \pm 3.24 \\
\mathrm{C}\end{array}$ & $\begin{array}{c}2.00 \pm .00 \\
\mathrm{C}\end{array}$ & $<.001^{*}$ \\
\hline 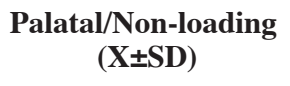 & $\begin{array}{c}141.00 \pm 9.66 \\
B\end{array}$ & $\begin{array}{c}9.00 \pm 3.74 \\
\mathrm{C}\end{array}$ & $<.001 *$ & $\begin{array}{l}38.00 \pm 5.24 \\
\mathrm{D}\end{array}$ & $\begin{array}{c}2.00 \pm 1.24 \\
\mathrm{C}\end{array}$ & $<.001^{*}$ \\
\hline p value & $<.001 *$ & $<.001^{*}$ & & $<.001 *$ & $<.001 *$ & \\
\hline
\end{tabular}

TA; telescopic attachments, BA; ball attachments. X: means, SD: st deviation. * p is significant at 5\%. The same letters show no difference between strain gauge positions. Different letters show a difference between strain gauge position 


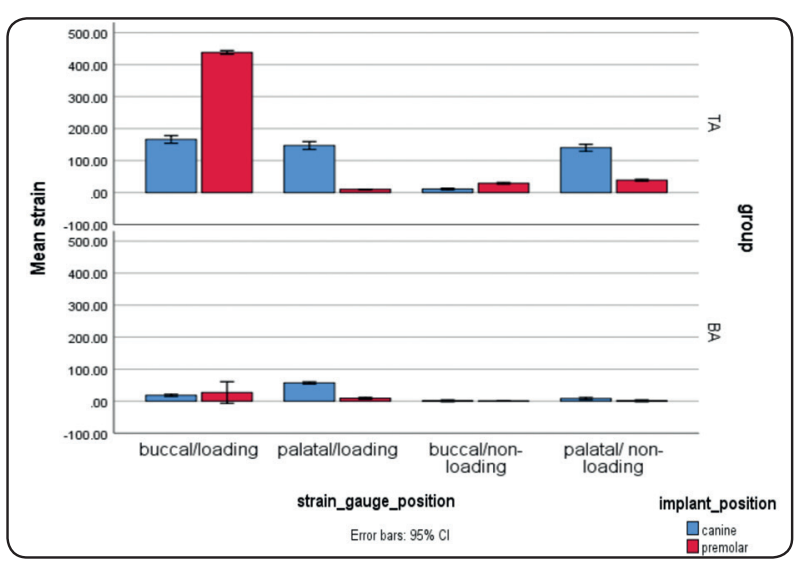

Fig. (5) Comparison of strains between implant positions for different groups and different strain gauge positions

\section{DISCUSSION}

In order to standardize implant position, strain gauge positions and loading, the position the same model was used for both attachments instead of construction of one model for each attachment. It is difficult to measure strains directly on the implants surface, but it is more feasible to measure strain occurs on the surface of bone around the implants represent the applied load on the implant ${ }^{35}$.Therefore 2 gauges were used for each implant at buccal and lingual aspects only. No strain gauges were mounted at mesial and distal aspects of each implant. The gauges were placed in the buccolingual direction because there was no room for them in the mesiodistal direction around the implants inserted in canine and second premolar positions because of the near proximity of the implants to each other. ${ }^{36}$ Moreover, Takahashi, et al. ${ }^{37}$ found that palatolabial strain was much higher on the implant than mediodistal strains. A 100 Newton force was applied to simulate the normal occlusal mastication forces and close to maximal loads for implant overdenture patients $^{34,38-40}$

For major strain gauges of canine and premolar implants, telescopic attachment recorded significant higher microstrains than ball attachments. The increased microstrain with telescopic attachment may be due to the rigid nature of the telescopes as there is no relieve (circumferential spaces) or tapering was made between the primary and secondary crowns. Furthermore, telescopic attachment has parallel walls, and increased vertical height (about $6 \mathrm{~mm}$ ) which produce vertical cantilever and limit rotational movement during loading. In addition, the increased surface area of friction between primary and secondary copings produce higher retention and stability values ${ }^{25}$ and could contribute significantly to increased stresses transmitted to the implants. Moreover, telescopic attachments have the higher contact point to the denture base than ball attachment which reported to produce greater stress to the implants ${ }^{26}$. In line with these findings, Elsyad, et al ${ }^{25}$ found that the increased height of telescopic attachments make them disconnect slowly during posterior dislodging when compared to milled bars. This could transfer more forces to the implants. In contrast, Kazokoğlu and Akaltan ${ }^{27}$ found no difference in microstrain obtained around the implants and on the edentulous ridges by double crowns, bar and ball anchors retaining maxillary implant overdentures. The difference in the results may be attributed to the rigid major connector in the study of Kazokoğlu and Akaltan thich may provide splinting action to the implants and could be responsible for reduced implant strains. Clinically, telescopic attachments may be recommended for subjects with atrophied ridges and shallow palate to augment the stability of maxillary overdenture and to protect the weak bone by providing rigid connection and total implant support. However, caution should be made as these rigid attachments may increase peri-implant strains and could lead to marginal bone loss.

The reduced peri-implant strains with ball attachments may be attributed to the resiliency and stress breaking action of the ball and attachments since this attachment permit rotation of the overdenture during loading thus decrease force transmission to the implants and optimizing stress 
distribution between the implants and the ridge ${ }^{22}$. Moreover, Ball attachment is resilient vertically and horizontally ${ }^{17}$. In with this explanation, Porter et al. reported that Ball transfers reduced loads on the implants which could enhance good health of the surrounding bone ${ }^{32}$. The ball attachments also allow even distributions of axial tension and tolerate slight rotation of the denture ${ }^{20,41}$. Another explanation of the reduced stresses with ball attachment is a reduced vertical height of the ball attachment (3mm) compared to telescopic attachment $(6 \mathrm{~mm})$ which could facilitate disconnection of the metal housings from the ball during loading with reduction of vertical cantilever forces transmitted to the implants. However, it should be noted that the increased strain around implants with telescopic attachments compared to ball attachments does not necessarily lead to increased bone resorption clinically. Krennmair, et al ${ }^{5}$ found no difference in peri-implant bone resorption and success rate of implants retaining mandibular overdentures with telescopic and milled bar attachments.

For both groups at canine implants, palatal loading side showed the highest microstrains. This may be due to movement of the canine implants palatally upon load application on first molar area because the load was applied on the central fossa of $1^{\text {st }}$ molar which is located palatal to the position of canine implants. Therefore, the acrylic resin is compressed on the palatal side of the canine implants. Similarly, Takahashi, et al. ${ }^{26}$ observed that anterior implants supporting maxillary overdentures are compressed distally and palatally, while posterior ones are compressed buccally. For premolar implants, buccal loading gauges showed the highest microstrain. This could be attributed to the deformation of maxillary implant overdenture away from the midline when load is applied ${ }^{42}$, indicating that implants were predominantly strained from palatal to buccal ${ }^{26}$. Osman et al. ${ }^{43}$ also found highest stresses at the distobuccal region of the 4 implants used to support maxillary overdentures with ball attachments under vertical and oblique loading conditions.

Canine implants recorded significant higher strain than premolar implants at palatal loading and palatal non-loading site. This may be due to movement of the canine implants palatally upon load application on first molar area as stated previously. Therefore, more force on acrylic resin around the palatal side of the canine implants occurs. Premolar implants recorded significant higher strain than canine implants at buccal loading and buccal non loading site. This could be attributed to the movement of the denture base from palatal to buccal direction when load was applied in the posterior region of maxillary implant overdentures ${ }^{43}$. The close proximity of premolar implants to the site of load application could be responsible for increased premolar strain compared to canine strains at buccal strain gauges. The premolar implants recorded the highest microstrain as they form a fulcrum during posterior loading of the overdenture ${ }^{36}$.

One of the limitations of this study is that acrylic resins do not replicate the mechanical properties of natural bone ${ }^{36}$. Moreover, the effect of vertical force only was investigated. The absence of nonaxial loading which commonly occur during mastication is another limitation as the direction of the load can change the patterns of tension. In addition, bilateral loading which represent clenching in centric occlusion was not tested. Further studies may be needed to evaluate the load transfer characteristics to peri-implant bone with different load directions and different attachments for maxillary implant overdentures. Also, randomized clinical trials are needed to examine the marginal bone loss associated with the tested attachments.

\section{CONCLUSION}

Within the limitation of this invitro study, ball attachments are recommended to retain maxillary implant overdenture than telescopic attachments as it were associated with reduced peri-implant strain. 


\section{REFERENCES}

1. Mericske-Stern RD, Taylor TD, Belser U. Management of the edentulous patient. Clin Oral Implants Res 2000; 11 Suppl 1: 108-125.

2. Sadowsky SJ. Treatment considerations for maxillary implant overdentures: a systematic review. J Prosthet Dent 2007; 97: 340-348.

3. da Silva RJ, Issa JP, Semprini M, da Silva CH, de Vasconcelos PB, Celino CA, Siessere S, Regalo SC. Clinical feasibility of mandibular implant overdenture retainers submitted to immediate load. Gerodontology 2011; 28: 227-232.

4. Thiel CP, Evans DB, Burnett RR. Combination syndrome associated with a mandibular implant-supported overdenture: a clinical report. J Prosthet Dent 1996; 75: 107-113.

5. Krennmair G, Suto D, Seemann R, Piehslinger E. Removable four implant-supported mandibular overdentures rigidly retained with telescopic crowns or milled bars: a 3-year prospective study. Clin Oral Implants Res 2012; 23 : 481-488.

6. Heckmann SM, Schrott A, Graef F, Wichmann MG, Weber HP. Mandibular two-implant telescopic overdentures. Clin Oral Implants Res 2004; 15: 560-569.

7. Heckmann SM, Winter W, Meyer M, Weber HP, Wichmann MG. Overdenture attachment selection and the loading of implant and denture-bearing area. Part 2: A methodical study using five types of attachment. Clin Oral Implants Res 2001; 12: 640-647.

8. Heckmann SM, Winter W, Meyer M, Weber HP, Wichmann MG. Overdenture attachment selection and the loading of implant and denture-bearing area. Part 1: In vivo verification of stereolithographic model. Clin Oral Implants Res 2001; 12: 617-623.

9. ELsyad MA, Denewar BA, Elsaih EA. Clinical and Radiographic Evaluation of Bar, Telescopic, and Locator Attachments for Implant-Stabilized Overdentures in Patients with Mandibular Atrophied Ridges: A Randomized Controlled Clinical Trial. The International journal of oral \& maxillofacial implants 2018; 33: 1103-1111.

10. ELsyad MA, Fathe Mahanna F, Samir Khirallah A, Ali Habib A. Clinical denture base deformation with different attachments used to stabilize implant overdentures: A crossover study. Clin Oral Implants Res 2019.

11. ELsyad MA, Ibrahim AE, Nawar NHH, Belal TM. Electromyographic Connectivity of Masseter Muscle with
Different Retentive Attachments for Implant Overdentures in Patients with Atrophied Mandibular Ridges: A Crossover Study. Int J Oral Maxillofac Implants 2019; 34: 1213-1222.

12. Mahanna FF, Elsyad MA, Mourad SI, Abozaed HW. Satisfaction and Oral Health-Related Quality of Life of Different Attachments Used for Implant-Retained Overdentures in Subjects with Resorbed Mandibles: A Crossover Trial. Int J Oral Maxillofac Implants 2020; 35: 423-431.

13. Fenlon MR, Palmer RM, Palmer P, Newton JT, Sherriff M. A prospective study of single stage surgery for implant supported overdentures. Clin Oral Implants Res 2002; 13: 365-370.

14. Gulizio MP, Agar JR, Kelly JR, Taylor TD. Effect of implant angulation upon retention of overdenture attachments. J Prosthodont 2005; 14: 3-11.

15. Alsabeeha NH, Payne AG, Swain MV. Attachment systems for mandibular two-implant overdentures: a review of in vitro investigations on retention and wear features. Int J Prosthodont 2009; 22: 429-440.

16. Petropoulos VC, Smith W. Maximum dislodging forces of implant overdenture stud attachments. Int J Oral Maxillofac Implants 2002; 17: 526-535.

17. Chung KH, Chung CY, Cagna DR, Cronin RJ, Jr. Retention characteristics of attachment systems for implant overdentures. J Prosthodont 2004; 13: 221-226.

18. Wiemeyer A, Agar J, Kazemi R. Orientation of retentive matrices on spherical attachments independent of implant parallelism. J Prosthet Dent 2001; 86: 434-437.

19. Walton JN, MacEntee MI, Glick N. One-year prosthetic outcomes with implant overdentures: a randomized clinical trial. Int J Oral Maxillofac Implants 2002; 17: 391-398.

20. Krennmair G, Weinlander M, Krainhofner M, Piehslinger E. Implant-supported mandibular overdentures retained with ball or telescopic crown attachments: a 3-year prospective study. Int J Prosthodont 2006; 19: 164-170.

21. Elsyad MA, Khirallah AS. Circumferential bone loss around splinted and nonsplinted immediately loaded implants retaining mandibular overdentures: A randomized controlled clinical trial using cone beam computed tomography. J Prosthet Dent 2016; 116 741-748

22. Tokuhisa M, Matsushita Y, Koyano K. In vitro study of a mandibular implant overdenture retained with ball, magnet, or bar attachments: comparison of load transfer and denture stability. Int J Prosthodont 2003; 16: 128-134. 
23. Isidor F. Influence of forces on peri-implant bone. Clin Oral Implants Res 2006; 17 Suppl 2: 8-18.

24. ELsyad MA, Elhaddad AA, Khirallah AS. Retentive Properties of O-Ring and Locator Attachments for ImplantRetained Maxillary Overdentures: An In Vitro Study. J Prosthodont 2018 Jul;27(6):568-576.

25. ELsyad MA, Soliman TA, Khalifa AK. Retention and Stability of Rigid Telescopic and Milled Bar Attachments for Implant-Supported Maxillary Overdentures: An In Vitro Study. Int J Oral Maxillofac Implants 2018; 33: e127-e133.

26. Takahashi T, Gonda T, Maeda Y. Effect of Attachment Type on Implant Strain in Maxillary Implant Overdentures: Comparison of Ball, Locator, and Magnet Attachments. Part 1. Overdenture with Palate. Int J Oral Maxillofac Implants 2017.

27. Kazokoglu FS, Akaltan F. Strain characteristics of Marburg double crown-retained implant overdentures compared with bar and ball-retained implant overdentures, with and without a rigid major connector. J Prosthet Dent 2014; 112: 1416-1424.

28. MA EL, El Ghany Kabil AA, El Mekawy N. Effect of Implant Position and Edentulous Span Length on Stresses Around Implants Assisting Claspless Distal Extension Partial Overdentures: An In Vitro Study. J Oral Implantol 2017; 43: 100-106.

29. ELsyad MA, Omran AO, Fouad MM. Strains Around Abutment Teeth with Different Attachments Used for Implant-Assisted Distal Extension Partial Overdentures: An In Vitro Study. J Prosthodont 2017 Jan;26(1):42-47.

30. Elsyad MA, Abid KS, Abd Elkhalek E. Effect of buccal implant inclination on stresses around two implant overdentures with resilient stud attachments. Int J Oral Maxillofac Implants 2017;32(3):e135-e142

31. Elsyad MA, Elhddad AA, Khirallah AS. The effect of implant diameter on strain around implants retaining a mandibular overdenture with Locator attachments: An in vitro study. Dent Mater J 2016; 35: 938-945.

32. Porter JA, Jr., Petropoulos VC, Brunski JB. Comparison of load distribution for implant overdenture attachments. Int $\mathrm{J}$ Oral Maxillofac Implants 2002; 17: 651-662.

33. Elsyad MA, Eltowery SM, Gebreel AA. Peri-implant strain around mesially inclined two implants retaining mandibular overdentures with Locator attachments. J Oral Sci 2017: Dec 27;59(4):483-490.

34. ELsyad MA, Setta FA, Khirallah AS. Strains around distally inclined implants retaining mandibular overdentures with Locator attachments. An in vitro study. J Adv Prosthodont 2016; 8 116-124.

35. Assuncao WG, Barao VA, Tabata LF, de Sousa EA, Gomes EA, Delben JA. Comparison between complete denture and implant-retained overdenture: effect of different mucosa thickness and resiliency on stress distribution. Gerodontology 2009; 26: 273-281.

36. ELsyad MA, Elsaadawy MG, Abdou AM, Habib AA. Effect of different implant positions on strain developed around four implants supporting a mandibular overdenture with rigid telescopic copings. Quintessence Int 2013; 44: 679-686.

37. Takahashi T, Gonda T, Mizuno Y, Fujinami Y, Maeda Y. Influence of Palatal Coverage and Implant Distribution on Implant Strain in Maxillary Implant Overdentures. Int J Oral Maxillofac Implants 2016; 31: e136-142.

38. Elsyad MA, Abid KS, Elkhalek EA. Effect of Buccal Implant Inclination on Stresses Around Two-Implant-Retained Overdentures with Resilient Stud Attachments. Int J Oral Maxillofac Implants 2017; 32: e135-e142.

39. Elsyad MA, Eltowery SM, Gebreel AA. Peri-implant strain around mesially inclined two-implant-retained mandibular overdentures with Locator attachments. J Oral Sci 2017; 59: 483-490.

40. Alameldeen HE, Elsyad MA, Shawky AF, Khirallah AS. The Influence of Implant Inclination on Retention and Peri-implant Stresses of Stud-Retained Implant Overdentures During Axial and Nonaxial Dislodgments: An In Vitro Study. Int J Oral Maxillofac Implants 2020; 35: 543550 .

41. Branchi R, Vangi D, Virga A, Guertin G, Fazi G. Resistance to wear of four matrices with ball attachments for implant overdentures: a fatigue study. J Prosthodont 2010; 19: 614-619.

42. Takahashi T, Gonda T, Maeda Y. The influence of reinforcement on strain in maxillary complete dentures: a preliminary report. Int J Prosthodont 2011; 24: 273-276.

43. Osman RB, Elkhadem AH, Ma S, Swain MV. Titanium versus zirconia implants supporting maxillary overdentures: three-dimensional finite element analysis. Int J Oral Maxillofac Implants 2013; 28: e198-208. 